\title{
Late Turonian ammonites from Haute-Normandie, France
}

\author{
WILLIAM J. KENNEDY ${ }^{1}$ and ANDREW S. GALE ${ }^{2}$ \\ ${ }^{1}$ Oxford University Museum of Natural History, Parks Road, Oxford OX1 3PW and Department of \\ Earth Sciences, South Parks Road, Oxford OX1 3AN, United Kingdom. \\ E-mail:jim.kennedy@oum.ox.ac.uk \\ ${ }^{2}$ School of Earth and Environmental Sciences, University of Portsmouth, Portsmouth PO1 3QL, \\ United Kingdom. \\ E-mail:andy.gale@port.ac.uk
}

\begin{abstract}
:
Kennedy, W.J. and Gale, A.S. 2015. Late Turonian ammonites from Haute-Normandie, France. Acta Geologica Polonica, 65 (4), 507-524, Warszawa.

Upper Turonian chalks of Haute-Normandie yield a distinctive ammonite fauna within the Subprionocyclus neptuni ammonite Zone and the Plesiocorys (Sternotaxis) plana echinoid Zone. Well-localised material all comes from the phosphatic fauna of the Senneville 2 Hardground that marks the boundary between the Formation de Senneville and the Életot Member of the succeeding Formation de Saint-Pierre-en-Port. The association is dominated by Lewesiceras mantelli Wright and Wright, 1951, accompanied by Mesopuzosia mobergi (de Grossouvre, 1894), Lewesiceras woodi Wright, 1979, Subprionocyclus hitchinensis (Billinghurst, 1927), Subprionocyclus branneri (Anderson, 1902), Subprionocyclus normalis (Anderson, 1958), Allocrioceras nodiger (F. Roemer, 1870), Allocrioceras billinghursti Klinger, 1976, Hyphantoceras reussianum (d'Orbigny, 1850), Sciponoceras bohemicum bohemicum (Fritsch, 1872), and Scaphites geinitzii d'Orbigny, 1850. The fauna represents the Hyphantoceras reussianum Event of authors, elements of which have been recognised on the north side of Tethys from Northern Ireland to the Mangyschlak Mountains of western Kazakstan, a distance of more than 3,500 kilometres.
\end{abstract}

Keywords: Ammonites; Cretaceous; Turonian; Haute-Normandie; Western France.

\section{INTRODUCTION}

The Hyphantoceras reussianum Event is an important marker within the Upper Turonian event stratigraphy sequence recognised in Western Europe (Wiese et al. 2004), characterised by a diverse ammonite assemblage in which heteromorphs are prominent. Genera present are Mesopuzosia, Lewesiceras, Tongoboryceras, Pseudojacobites, Subprionocyclus, Allocrioceras, Metaptychoceras, Hyphantoceras, Eubostrychoceras, Neocrioceras, Sciponoceras, Baculites, Yezoites, and
Scaphites. This diverse fauna can be recognised from southern and eastern England (Crick 1910; Dibley 1912; Wright 1979) to Westphalia and Saxony in Germany (Ernst et al. 1983; Kaplan 1991, 2011), the Czech Republic (Čech 1989), Poland (Walaszczyk 1988, 1992; Tarkowski 1991), northern Spain (Küchler and Ernst 1989), and more than $3,500 \mathrm{~km}$ to the east in the Mangyshlak Mountains of Kazakhstan (Marcinowski et al. 1996). Supposed Cenomanian Eubostrychoceras and Hyphantoceras from tobratrondgerda collected by

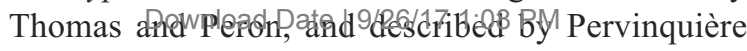




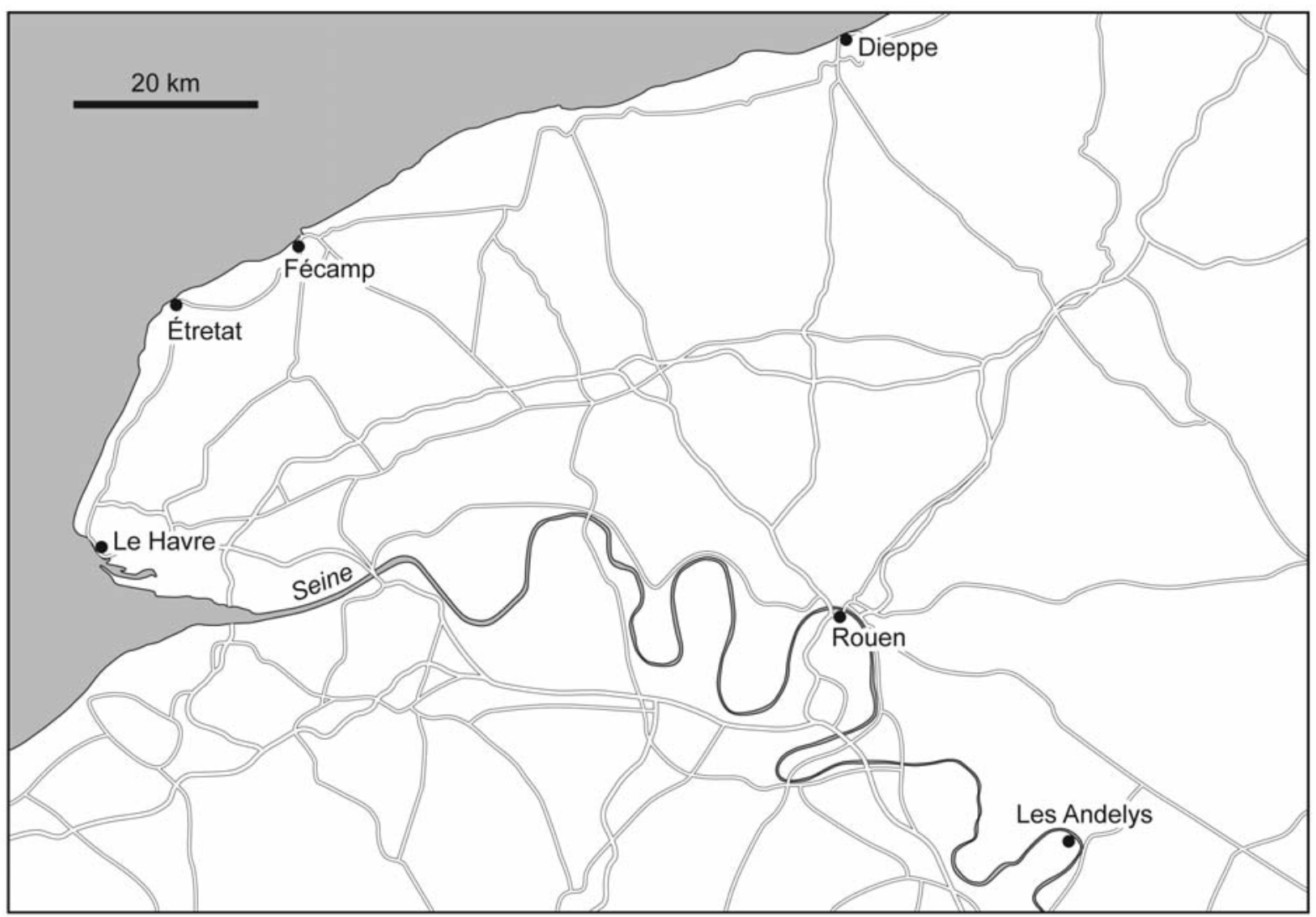

Text-fig. 1. Position of localities in Haute-Normandie mentioned in the text

(1910) demonstrate the presence of the event on the south side of Tethys (Kaplan and Kennedy 1996). In France, elements of the event fauna were described from Uchaux in Vaucluse by d'Orbigny (1840-42) Roman and Mazeran (1913), and Amédro and Devalque (in Robaszynski et al. 2014), who illustrate a number of the

\begin{tabular}{|c|c|c|c|c|}
\hline STAGE & FORMATION & MEMBER & FACIES & DISCONTINUITY \\
\hline CONIACIAN (pars) & \multirow{3}{*}{$\begin{array}{c}\text { Saint-Pierre- } \\
\text { en-Port } \\
\text { (pars) }\end{array}$} & & & \multirow{2}{*}{ - HG Petites Dalles - } \\
\hline \multirow{5}{*}{ TURONIAN } & & Petites Dalles & Chalk with small flints & \\
\hline & & Életot & Nodular Chalk & \\
\hline & \multicolumn{2}{|c|}{ Senneville } & $\begin{array}{c}\text { Chalk with beds } \\
\text { of marl }\end{array}$ & \\
\hline & \multirow{2}{*}{ Tilleul } & $\begin{array}{l}\text { Val Saint- } \\
\text { Nicolas }\end{array}$ & $\begin{array}{l}\text { Chalk with } \\
\text { Thalassinoides flints }\end{array}$ & \multirow{2}{*}{ — HG Fagnet } \\
\hline & & Cap Fagnet & $\begin{array}{c}\text { Nodular Chalk with } \\
\text { Mytiloides }\end{array}$ & \\
\hline
\end{tabular}


species present. Elsewhere in France, there are records from the Boulonnais (Amédro et al. 1978, 1979; Amédro and Robaszynski 2000, 2001), Artois (Amédro and Robaszynski 2006), and Aube (Amédro et al. 1982).

We describe and figure representatives of the reussianum fauna from a series of localities in HauteNormandie (Text-fig. 1). Records of the presence of ammonites in Upper Turonian chalks, commonly referred to a Zone à Holaster planus, are to be found in the works of Hébert (for example 1875, p. 520), part of whose collection we describe below, and other Nineteenth Century authors. The most detailed record of the ammonites present was given by de Grossouvre (1901, pp. 123-4), who, in his account of the cliffs of Haute-Normandie, wrote as follows: “L'assise supérieur est constituée par une craie marneuse à Terebratulina gracilis, Inoceramus Brongniarti, Spondylus spinosus, et se termine par un lit fossilifère assez constant dans la region et characterise par Sonneratia perampla (Am. Prosperianus, auct.), Scaphites Geinitzi et Rhynchonella plicatilis. Au-dessus, vient une assize peu épaisse de craie à Holaster planus, Micraster breviporus, Micraster corbovis, M. normanniae; dans les environs de Dieppe, M. Janet a recuilli à ce niveau des petites Céphalopodes." The "lit fossilifère assez constant" of de Grossouvre is the Senneville 2 Hardground of current lithostratigraphic nomenclature (Text-figs 2, 3; Juignet and Bréton 1994). Jukes-Browne and Hill (1904, p. 296) note the similarity of this unit, as exposed at the top of the Côte Sainte Catherine in Rouen, and at Villéquier, to the Chalk Rock of southern England, the top of which is the source of a diverse $\mathrm{Hy}$ phantoceras reussianum fauna (Wright 1979).

\section{STRATIGRAPHY}

The lithostratigraphic terminology used here is that of Juignet and Bréton (1994), as shown in Text-fig. 2. Our own collection of material, described below, is from the Senneville 2 Hardground that marks the top of the Formation de Senneville on the coast at Sennevillesur-Fécamp (Text-fig. 1), and the base of the succeeding Formation de Saint-Pierre-en-Port. Text-fig. 3 is a detailed log of the sequence, showing the local lithostratigraphic divisions, and marker beds that can be recognised across the Anglo-Paris Basin (Mortimore 1986; Mortimore and Pomerol 1987). The lower part of the succession exposed at Senneville (Text-fig. 3), at the 1-2 $\mathrm{m}$ level, is marked by two massively indurated, glauconitised hardgrounds which form the shore platform to the west of the cliff path. These are the Tilleul Hardgrounds 1-2 of Kennedy and Juignet (1974), which probably correlate with the Ogbourne Hardground of the

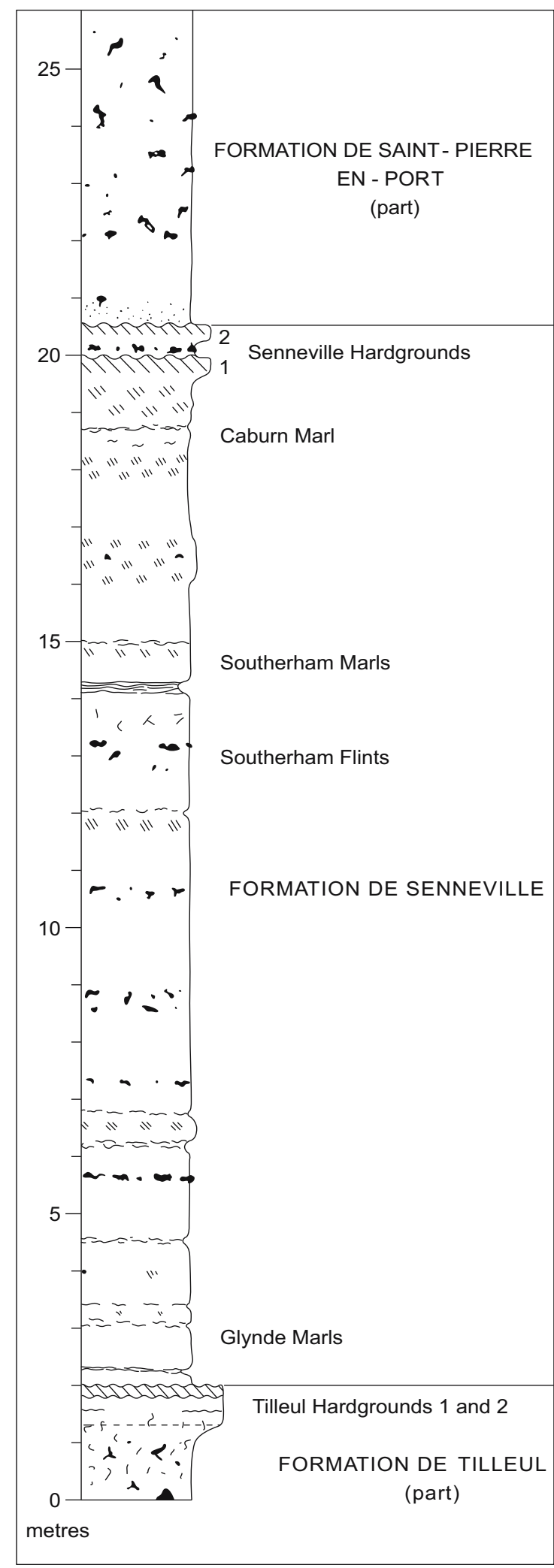

Text-fig. 3. The lithological succession in the uppermost Craie de Tilleul,Craie

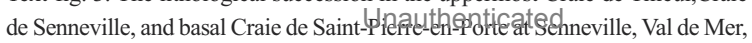
Download Dateme-knarifing 1:08 PM 
Chalk Rock succession in southern England (Gale 1996). Above this, a distinctive marl seam at the14.2$14.3 \mathrm{~m}$ level, overlying a level of Thalassinoides flints, represents the Southerham Marl of the UK succession (Mortimore 1986), which is volcanigenic in origin (Wray 1999). At the $19.8 \mathrm{~m}$ level, a thin representation of the Caburn Marl is developed. Two well developed hardgrounds, the Senneville Hardgrounds 1-2 of Juignet

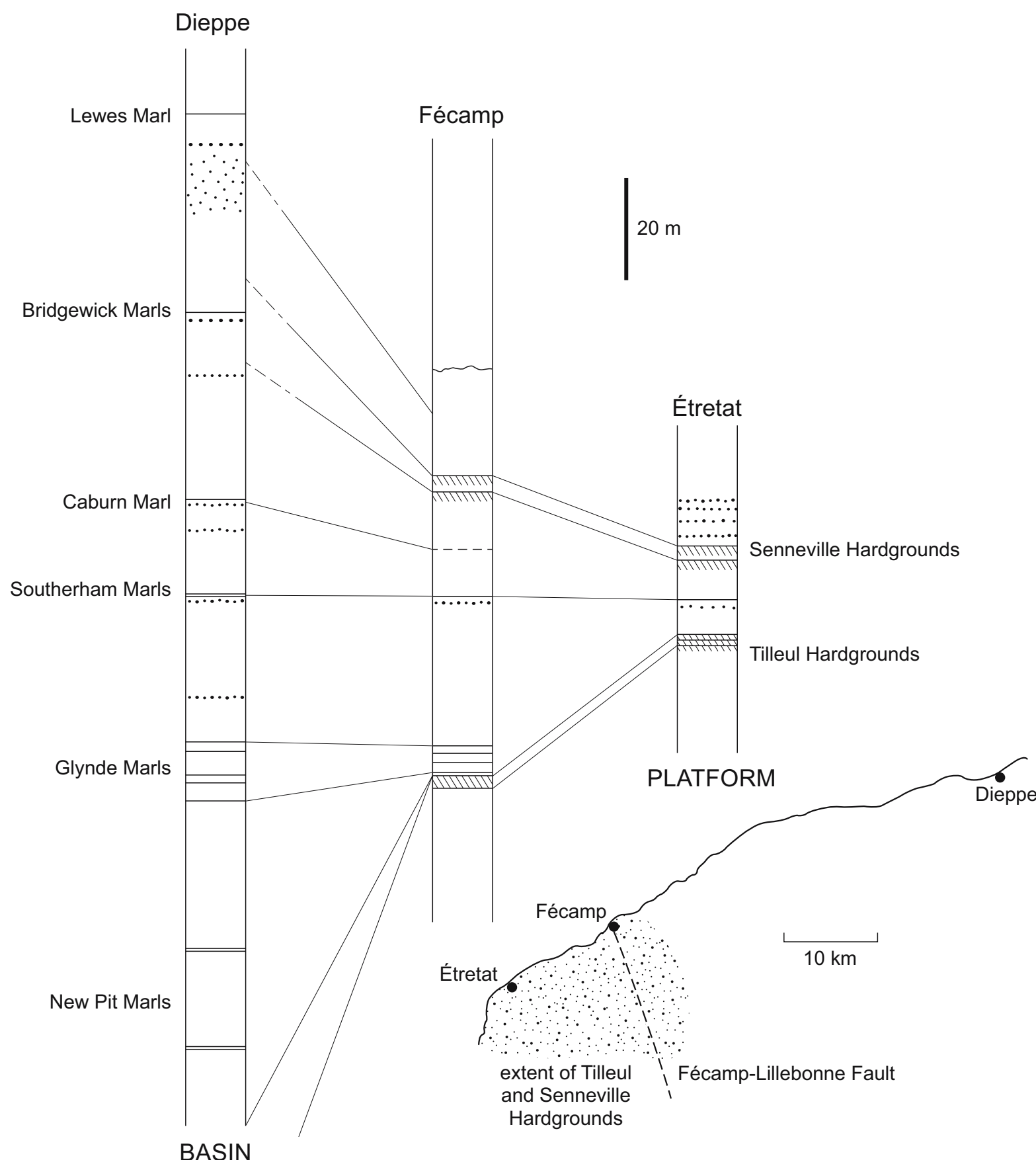

and Breton (1994) are present at the 19.7-20.6 m level. The higher of these has a hummocky surface, replaced superficially by pale brown phosphate, and contains open Thalassinoides galleries. The Senneville 2 Hardground is overlain by $0.2 \mathrm{~m}$ of coarse calcarenitic chalks of the basal Formation-de-Saint-Pierre-en-Port, containing sparse phosphatised intraclasts. Ammonites are preserved in the upper part of Senneville 2, and as intr-

\section{Dieppe}


aclasts in the overlying calcarentitic chalk. The Senneville Hardgrounds are equivalent to the Hitch Wood Hardground of the English Chalk Rock sequence (Bromley and Gale 1982; Gale 1996), which also yields an abundant ammonite fauna locally (Wright 1979). The overlying chalks of the basal Saint-Pierre-en-Port Formation at the 21-26 m level contain silicified Thalassinoides flints, equivalent to the Lewes Tubular Flints of Mortimore (1986).

Text-fig. 4 traces the changes in the succession along the Normandy coast from Étretat to Dieppe. The Senneville Hardgrounds, together with the underlying Étretat Hardgrounds are developed over an area to the west of the Fécamp-Lillebonne Fault. It will be seen that the succession increases in thickness from Étretat to Fécamp, with the latter close to the fault line and the change to more basinal facies, as at Dieppe, where there are no hardgrounds, the thick succession of chalks with marl beds and flints including a full complement of the marker marls of the Anglo-Paris Basin succession.

\section{THE FAUNA}

We have seen 36 ammonites in all, in our own collections and those of the Sorbonne. Lewesiceras mantelli Wright and Wright, 1951 is numerically dominant, making up 36\% of the assemblage, with Sciponoceras bohemicum bohemicum (Fritsch, 1872) making up a further 19\%, and Hyphantoceras reussianum (d'Orbigny, 1850) $11 \%$. The remaining species, are: Mesopuzosia mobergi (de Grossouvre, 1894), Lewesiceras woodi Wright, 1979, Subprionocyclus hitchinensis (Billinghurst, 1927), Subprionocyclus branneri (Anderson, 1902), Subprionocyclus normalis (Anderson, 1958), Allocrioceras nodiger (F. Roemer, 1870), Allocrioceras billinghursti Klinger, 1976, and Scaphites geinitzii (d'Orbigny, 1850)

This ammonite fauna is typical of the Hyphantoceras reussianum Event, in the upper part of the lower Upper Turonian Subprionocyclus neptuni Zone. The dominance of Lewesiceras mantelli is a typical feature of assemblages from the correlative Hitch Wood Hardground at the top of the Chalk Rock of southern England. Apart from the species listed above, and described below, there is a further species from Haute-Normandie that is probably from the Upper Turonian: a $126 \mathrm{~mm}$ long phragmocone assigned to Baculites undulatus d'Orbigny, 1850, collected from a loose block on the beach at Életot and described by Bréton and Bavent (1985, p. 101, figs 1-3).

Associated fauna collected from and immediately above the Senneville 2 Hardground is Micraster leskei
Desmoulins, 1837, Conulus subrotundus Mantell, 1822, Plesiocorys (Sternotaxis) plana (Mantell, 1822), Eutrephoceras sublaevigatum (d'Orbigny, 1840), 'Turbo' geinitzi Woods, 1896, Pleurotomaria sp., Avellana sp., Spondylus spinosus (J. Sowerby, 1814), Inoceramus sp., Gibbithyris sp., Ventriculites and other hexactinellid sponges.

\section{REPOSITORIES OF SPECIMENS}

BMNH: The Natural History Museum, London.

MNHP: The Laboratoire de Paléontologie of the Muséum National d'Histoire Naturelle, Paris.

OUM: The Oxford University Museum of Natural History.

SAM: The Iziko South African Museum, Cape Town. SP: The collections of the Sorbonne, housed in the Université Pierre et Marie Curie, Paris VI.

\section{SYSTEMATIC PALAEONTOLOGY}

In the account of the fauna given below, we provide limited synonymies only. Comprehesive synonymies and discussions (notably of Subprionocyclus species) will appear in a forthcoming revision of the Turonian ammonite faunas of the Münsterland Cretaceous Basin in Germany (in preparation).

Order Ammonoidea Zittel, 1884

Suborder Ammonitina Hyatt, 1889

Superfamily Desmoceratoidea Zittel, 1895

Family Desmoceratidae Zittel, 1895

Subfamily Puzosiinae Spath, 1922

Genus Mesopuzosia Matsumoto, 1954

TYPE SPECIES: Mesopuzosia pacifica Matsumoto, 1954, p. 82, pl. 14, fig. 1; pl. 15, figs 1, 2; pl. 16, figs $1-$ 3 ; text-fig. 2 , by original designation by Matsumoto (1954, p. 79).

Mesopuzosia mobergi (de Grossouvre, 1894)

(Text-fig. 5E, F, L, M)

1872. Ammonites austeni Sharpe; Schlüter, p. 38, pl. 11, fig. 11.

1894. Pachydiscus mobergi de Grossouvre, p. 189.

1909. Puzosia curvatisulcatal ShatteinicanddWithers, p. 68 , pl. 2, Thigstload Date | 9/26/17 1:08 PM 


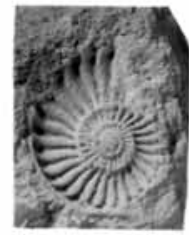

A

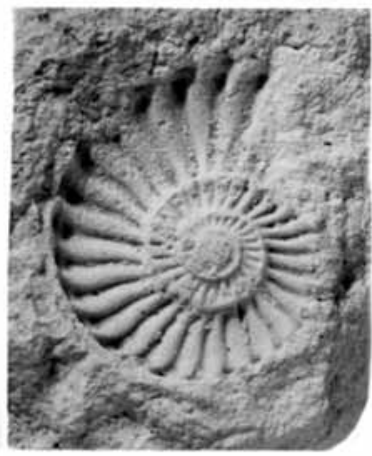

C
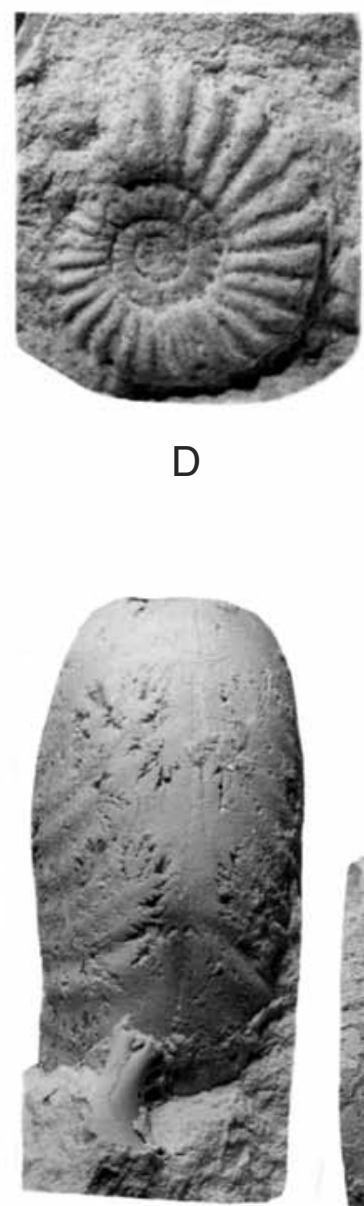

L

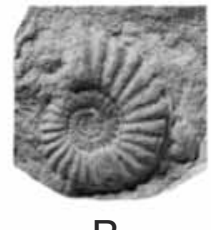

B

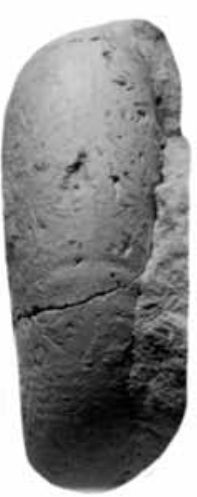

E
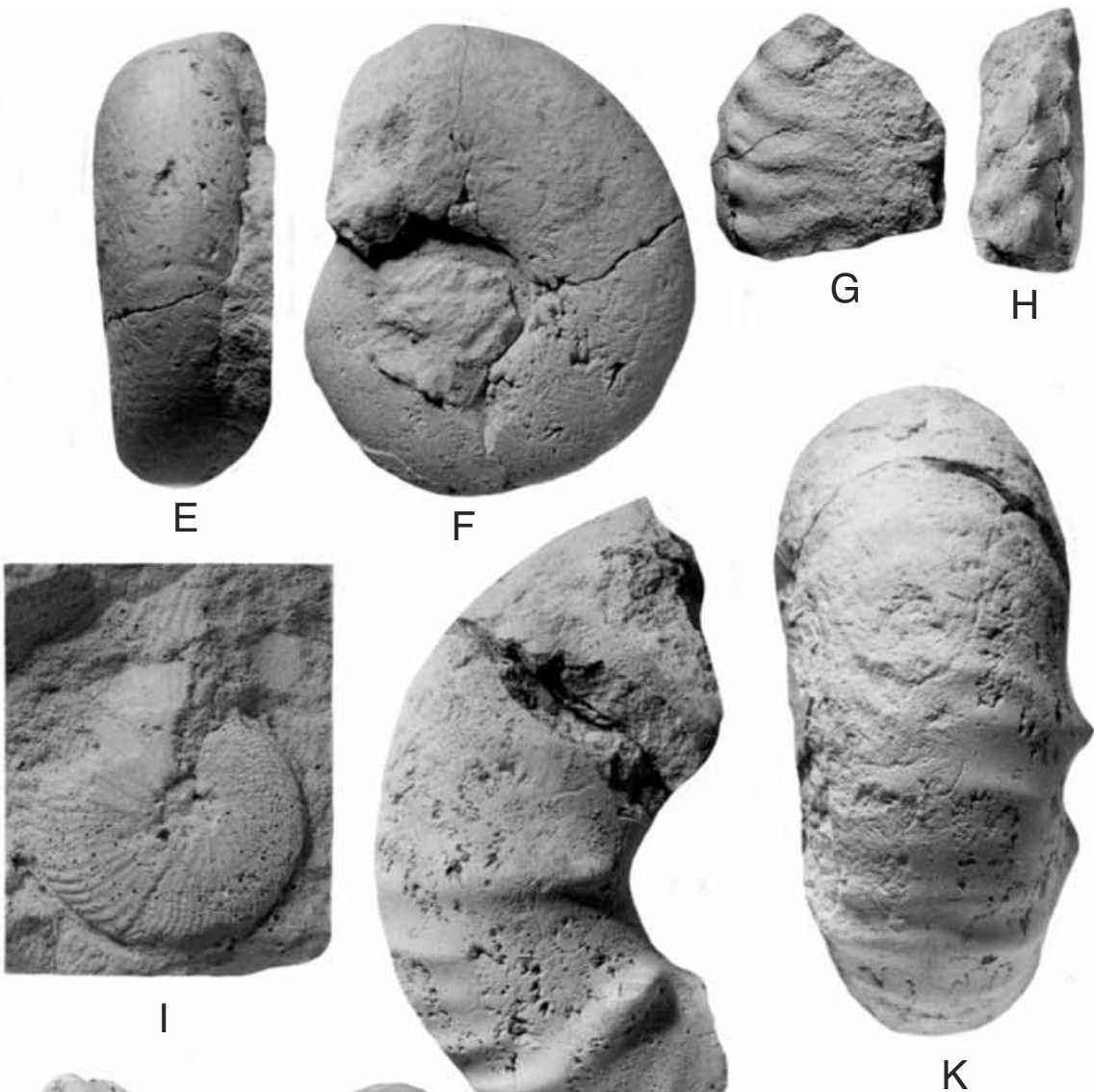
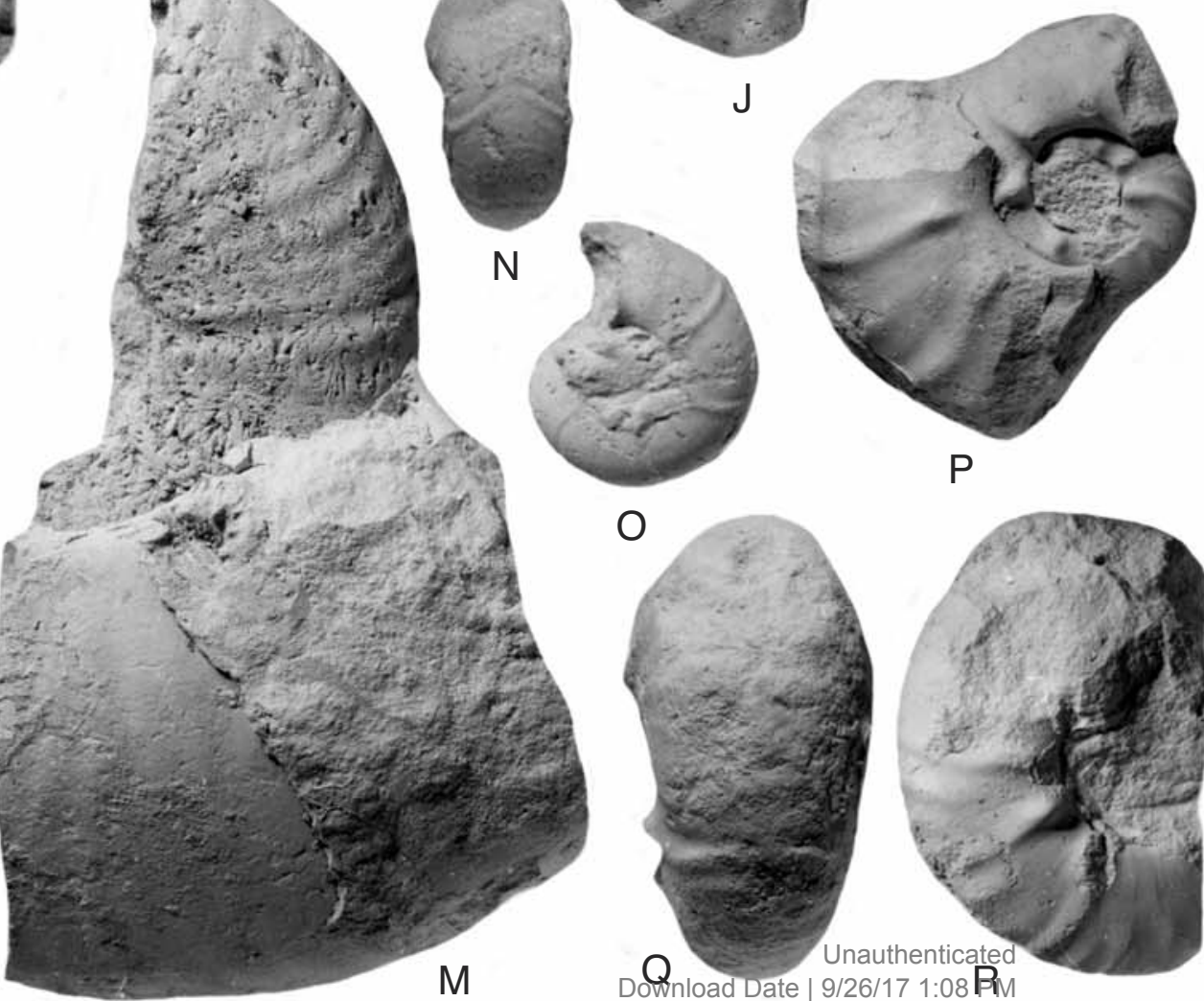
1913. Puzosia gaudemarisi Roman and Mazerin, p. 19, pl. 2 , figs 1,2 .

1979. Puzosia curvatisulcata Chatwin and Withers; Wright, p. 308 , pl. 4, fig. 4 ; pl. 7 , fig. 3 .

1994. Mesopuzosia mobergi (de Grossouvre, 1894); Kaplan and Kennedy, p. 35, pl. 4 (with additional synonymy).

TYPES: Schlüter based his Ammonites austeni on two specimens. The original of his pl. 11, fig. 11, was in the collections of the Bonn University, Poppelsdorf, and from the Upper Turonian "Grünsand mit Spondylus spinosus" of the Münsterland Cretaceous Basin, that is to say the Soest Greensand Member of current nomenclature. It has not been traced, nor has the second specimen (Kaplan and Kennedy 1994, p. 35).

MATERIAL: OUM KZ20991-2, KZ26704, from the Upper Turonian neptuni/plana Zone, Senneville 2 Hardground at the top of the Formation de Senneville at Senneville.

DESCRIPTION: OUM KZ20992 (Text-fig. 5E, F) is a phosphatised internal mould of a phragmocone 43.7 $\mathrm{mm}$ in diameter. Coiling is moderately evolute, the umbilicus comprising $30 \%$ approximately of the diameter, shallow, with a low, flattened wall and rounded umbilical shoulder. The whorl section is compressed, with a whorl breadth to height ratio of 0.8 approximately, the inner and middle flanks feebly convex, the outer flanks converging to broadly rounded ventrolateral shoulders and a convex venter. There are three constrictions visible on the outer whorl of the specimen, set $90^{\circ}$ approximately apart. They are very feeble, straight and prorsirsdiate on the inner and middle flank, but strengthen, sweep forwards, are concave on the outer flank and ventrolateral shoulder, and best-developed on the venter, where they are feebly convex, and associated with a very feeble adapical collar rib. The surface of the mould between successive constrictions is ornamented by numerous fine ribs, conspicuous only on the ventrolateral shoulders, where they are feebly concave, and on the venter, which they cross in a broad convexity. OUM KZ26704 (Text-fig. 5L, M) is an internal mould of half a whorl of phosphatised phragmocone $68 \mathrm{~mm}$ in diameter, and a $60^{\circ}$ sector of body chamber with a maximum preserved whorl height of $52 \mathrm{~mm}$. The coiling of the phragmocone fragment is moderately involute, the umbilicus comprising 29\% approximately of the diameter. The umbilicus is shallow, the wall flattened, the umbilical shoulder quite narrowly rounded. The whorl section is compressed, with a whorl breadth to height ratio of 0.85 . The greatest breadth is below mid-flank, the inner and middle flanks are feebly convex, the outer flanks flattened and convergent, the ventrolateral shoulders broadly rounded, the venter feebly convex. Two strong, narrow constrictions are present. They are deeply incised into the umbilical shoulder, straight and feebly prorsiradiate on the inner to middle flanks, flexing forwards and concave on the outer flank and ventrolateral shoulder, and crossing the venter in an obtuse linguoid peak. There is a weak adapical collar rib on the ventrolateral shoulder. Successive constrictions are separated by strong, narrow ribs, an estimated 10 in number, primaries and long intercalated ribs, one of which branches on the ventrolateral shoulder. They are falcoid, straight and prorsirsdiate on the inner flanks, flexing back and then forwards to become markedly concave on the outer flank and ventrolateral shoulder, and projecting strongly forwards on the venter, where they weaken and form a $90^{\circ}$ chevron. On the body chamber fragment, the same pattern of ribbing is present, with predominantly primary ribs, one of which bifurcates on the outer flank. The third fragment, OUM KZ20991, is still septate at a whorl height of $50 \mathrm{~mm}$.

DISCUSSION: The larger of these fragments compare well with the lectotype at the same whorl height, the Westphalian example figured by Kaplan and Kennedy (1994, pl. 4), and the better preserved holotype of Mesopuzosia gaudemarisi (Roman and Mazeran, 1913) (p. 19, pl. 2, fig. 1), a synonym, from the Upper Turonian of Uchaux, Vaucluse. This retains silicified shell, and the ornament is, as a result, sharper.

OCCURRENCE: Upper Turonian, neptuni/plana Zone of southern England; Haute-Normandie and Vaucluse in France. Upper Turonian to Middle Coniacian of Westphalia, Germany, and Middle Coniacian of Romania.

Family Pachydiscidae Spath, 1922 Genus Lewesiceras Spath, 1939

Text-fig. 5. A-D - Subprinocyclus branneri (Anderson, 1902). External mould (A, C) and contemporary plaster cast (B, D), SP, Hébert Collection, from Fécamp. E, F, L, M, Mesopuzosia mobergi (de Grossouvre, 1894). E, F - OUM KZ20992; L, M, OUM KZ, 26704, both from the Upper Turonian neptuni/plana Zone Senneville 2 Hardground at the top of the Formation de Senneville at Senneville. G, H - Subprionocyclus normalis (Anderson, 1958), SP, Hébert Collection, from Fécamp. I - Subprionocyclus hitchinensis (Billinghurst, 1927), OUM KZ26706, cast of a specimen in the collections of the Muséum d'Histoire Naturelle, le Havre, from Puys, 3km northeast of Dieppe. J, K, P-R - Lewesiceras mantelli Wright and Wright, 1951. J, K, Q, R, SP, Hébert Collection, from Fécamp; P, OUM KZ26705, from the Upper Turonian neptuni/plana Zone Senneville 2 Hardground at the top of the Formation de Senneville at Senneville. N, O

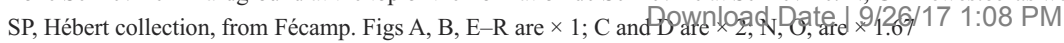


TYPE SPECIES: Ammonites peramplus Mantell, 1822, p.200, by original designation by Spath 1939, p. 296.

Lewesiceras mantelli Wright and Wright, 1951

(Text-fig. 5J, K, P, Q, R)

1853. Ammonites peramplus Mantell; Sharpe, p. 26 (pars), pl. 10, figs 2,3 only.

1951. Lewesiceras mantelli Wright and Wright, p. 20.

1967. Lewesiceras mantelli Wright and Wright; Houša, p. 26, pl. 4 , fig. 3 only; pl. 5, figs $1-4$; pl.6, figs $1-4$.

1967. Lewesiceras lenesicense Houša, p. 35, pl. 8 figs 1-7.

1979. Lewesiceras mantelli Wright and Wright; Wright, p. 310, pl. 4, figs 1-3; pl. 6, figs 4, 5 (with synonymy).

2014. Lewesiceras mantelli (Wright and Wright, 1951); Amédro and Devalque in Robaszynski et al., p. 133, pl. 34, fig. 3; pl. 37, fig. 2; pl. 39, figs 9, 10.

TYPE: Lewesiceras mantelli was introduced by Wright and Wright (1951, p. 20) as nomen novum for Pachydiscus cricki Spath, 1926 (p. 82) non Kossmat, 1898 (p. 105 (170), pl. 15 (21), fig. 3), of which the holotype by monotypy is BMNH 88587, the original of Sharpe 1853, pl. 10, Fig. 3, from Oldbury Hill, Wiltshire.

MATERIAL: SP: nine specimens in the Hébert Collection, labelled "Am.peramplus jeune (Am. Prosperianus d'Orb.) craie à Holaster subglobosus, Fécamp". OUM KZ20983, 20985-2090, 26705, from the Upper Turonian neptuni/plana Zone Senneville 2 Hardground at the top of the Formation de Senneville at Senneville.

DESCRIPTION: The specimens are phosphatised, some with a green glauconitic coating, and range from 19.3 $72 \mathrm{~mm}$ in diameter. Coiling is evolute, the umbilicus comprising around $33 \%$ of the diameter, quite deep, with a convex wall and broadly rounded umbilical shoulder. The whorl section is depressed reniform, with intercostal whorl breadth to height ratios of around 1.1. Eight primary ribs per whorl arise at the umbilical seam and strengthen into massive subspinose umbilical bullae, perched on the umbilical shoulder. These give rise to a single coarse primary rib that is straight and prorsiradiate across the inner to middle flanks, strengthening, projecting forwards, and concave on the outer flank and ventrolateral shoulder, and crossing the venter in a broad convexity. One or two weaker ribs may be tenuously linked to the bullae, and there are also weak intercalated ribs on the outer flanks, ventrolateral shoulders, and venter. The strongest bullate primary ribs are succeeded or preceded by strong constrictions, bestdeveloped on the ventrolateral shoulders and venter.
DISCUSSION: The coarse strongly bullate primaries and strong intercalated ribs immediately distinguish the species from co-occuring Lewesiceras woodi Wright, 1979 (Text-fig. 5N, O), as discussed below.

OCCURRENCE: Upper Turonian, neptuni/plana Zone. The geographic distribution extends from Northern Ireland to southern and eastern England, France, Germany, The Czech Republic, Poland, Ukraine (Crimea), European Russia, Kazakhstan, and, possibly, Austria.

\section{Lewesiceras woodi Wright, 1979}

(Text-fig. $5 \mathrm{~N}, \mathrm{O}$ )

1973. Pseudopuzosia sp. Birkelund, p. 141, pl. 12.

1979. Lewesiceras woodi Wright, p. 312, pl.3, fig. 21; pl. 6, fig. 6 .

TYPES: The holotype is BMNH C79509, the original of Wright (1979, pl. 3, fig. 21), from the Upper Turonian neptuni/plana Zone of Hitch Wood, near Hitchin, Hertfordshire. Paratype BMNH C20239 is the original of Wright (1979, pl. 6, fig. 6), from the same horizon at Aston Rowant, Buckinghamshire. Paratype BMNH C79504 is presumed to be from the Upper Turonian plana Zone of Kent. Paratype BMNH C79520 is from the Upper Turonian plana Zone of Malling Hill, Lewes, Sussex. A further paratype is the original of Birkelund (1973, p. 141, pl. 12), from Särdal Sweden, no 12836 in the collections of the Geologisk Museum, Copenhagen.

MATERIAL: SP: a specimen in the Hébert Collection, labelled "Am. Peramplus jeune (Am. Prosperianus d'Orb.)...Craie à Holaster planus... Fécamp”.

DESCRIPTION: The specimen is a phosphatised internal mould $14 \mathrm{~mm}$ in diameter, with traces of a green, glauconitic coating. Coiling is very involute, the umbilical wall convex and outward-inclined, the whorl section compressed reniform, with a whorl breadth to height ratio of 1.25 , the greatest breadth below midflank. There are four narrow constrictions per half whorl, straight on the inner flank, and concave on the outer flank, projected forwards across the ventrolateral shoulder and crossing the venter in a broad convexity. The constrictions are preceded by a narrow collar rib that originates at a very feeble umbilical bulla. There are up to four ribs between successive constrictions/collar ribs, which they parallel. They are very feeble, and obvious only on the outerffandasnventrolateral shoulders and ventertoad Date | 9/26/17 1:08 PM 
DISCUSSION: The present specimen differs in no significant respects from the paratype of comparable size (Wright 1979, pl. 6, fig. 6). Lewesiceras woodi differs from Lewesiceras mantelli of comparable size (for example the inner whorls of the specimen illustrated here as Text-fig. 5P) in the much weaker umbilical tuberculation and very subdued ribbing between successive collar-ribs.

OCCURRENCE: Upper Turonian, neptuni/plana Zone, southern England, Haute-Normandie in France, and Särdal, Sweden.

Superfamily Acanthoceratoidea de Grossouvre, 1894 Family Collignoniceratidae Wright and Wright, 1951 Subfamily Collignoniceratinae Wright and Wright, 1951 Genus Subprionocyclus Shimizu, 1932 (= Reesidites Wright and Matsumoto, 1954 p. 130; Oregoniceras Anderson, 1958, p. 263; 1943, p. 185, nom, nud.; Ledoceras Basse, 1963, p. 871)

TYPE SPECIES: Prionocyclus hitchinensis Billinghurst, 1927, p. 516, pl. 16, figs 1, 2, by the original designation of Shimizu 1932, p. 2.

Subprionocyclus hitchinensis (Billinghurst, 1927) (Text-fig. 5I)

1927. Prionocyclus hitchinensis Billinghurst, p. 516, pl. 16, figs 1,2 .

1979. Subprionocyclus hitchinensis (Billinghurst); Wright, p. 318 (pars), pl. 5, figs 7, 10, ?non 9.

1988. Subprionocyclus hitchinensis (Billinghurst); Kaplan, p. 17, pl. 4, figs 1-3 (with synonymy).

2014. Subprionocyclus hitchinensis (Billinghurst, 1927); Amédro and Devalque in Robaszynski et al., p. 158, pl. 39, fig. 15.

TYPES: The holotype, by original designation is BMNH C32292, from the Upper Turonian neptuni/plana Zone fauna of the Chalk Rock of Hitch Wood, near Hitchin, Hertfordshire, the original of Billinghurst (1927, p. 516, pl. 16, fig. 1). Paratype BMNH C32293 is the original of Billinghurst (1927, pl. 16, fig. 2), from the same horizon and locality. Paratype BMH 23156 is from the 'Middle Chalk of Kent'.

MATERIAL: OUM 26706, a cast of a specimen in the collections of the Muséum du Havre, from the "Craie à bioclasts abondantes, à petites silex cornues" of the cliffs north of Puys, $3 \mathrm{~km}$ north-east of Dieppe.
DESCRIPTION: The specimen is an internal mould of one flank of an individual with a maximum preserved diameter of $34.5 \mathrm{~mm}$ approximately. The adapical $120^{\circ}$ sector is body chamber. The coiling is very involute, the umbilicus comprising 14\% approximately of the diameter. The whorl section is very compressed, the inner and middle flank region very feebly convex, the outer flanks flattened and slightly convergent, the ventrolateral shoulders broadly rounded. The venter is not preserved. Ribs arise on the umbilical wall, and strengthen into umbilical bullae, minute at the adapical end of the outer whorl, but stronger and better differentiated on the adapertural part. They give rise to one, two or three ribs, and additional ribs intercalate. The ribs are fine, mere lirae on the phragmocone, but strengthen on the body chamber. They are prorsiradiate, straight on the inner flank, flexing back at mid flank and forwards on the outer flank, where they are feebly concave, and strengthen progressively. The ventrolateral shoulder is damaged, but there is a single row of barely differentiate ventrolateral clavi on the phragmocone in places, but not, so far as can be seen on the body chamber.

DISCUSSION: Subprionocyclus hitchinensis is characterised by its very involute coiling, fine, crowded, flexuous ribs, and the presence of only a single row of ventral/ventrolateral tubercles, features that distinguish it from others referred to the genus.

OCCURRENCE: S. neptuni /plana Zone Chalk Rock of southern England; Haute-Normandy and Vaucluse in France, and Westphalia, Germany. Records from northern Spain, Austria, and Bulgaria are either doubtful, or belong to other species.

\section{Subprionocyclus branneri (Anderson, 1902)}

(Text-fig. 5A-D)

1902. Prionocyclus branneri Anderson, p. 125, pl. 1, figs 1116.

1958. Prionotropis branneri Anderson; Anderson, p. 261, pl. 34, figs 1-3.

1979. Subprionocyclus branneri (Anderson); Wright, p. 320, pl. 5, figs 4-6 (with synonymy).

2014. Subprionocyclus branneri (Anderson, 1902); Amédro and Devalque in Robaszynski et al., p. 158, pl. 39, fig. 11.

2014. Subprionocyclus branneri (Anderson, 1902); Wilmsen and Nagm, p. 224, text-fig. 13b.

TYPE: The lectotype, by the subsequent designation of Matsumoto (1959, p. 109), is the priginal of Anderson (1902, pl. D,ofig.dald, moe 48 inbthe colleetions of the Cal- 
ifornia Academy of Sciences, San Francisco, from the Fitch Ranch, west of Phoenix, Oregon.

MATERIAL: SP, Hébert Collection, an external mould (Text-fig. 5A, C), labelled: “A. neptuni Geinitz Tur. Inf. Zone sup à Sch. Geinitzi, M. Hébert. [Fécamp]" and a contemporary plaster cast (Text-fig. 5D).

DESCRIPTION: The external mould is $18 \mathrm{~mm}$ in diameter. Coiling is evolute, the umbilicus comprising $40 \%$ approximately of the diameter, shallow, with a low, convex wall and a broadly rounded umbilical shoulder. There are 28 ribs on the outer whorl, all primaries. They arise at the umbilical seam and strengthen across the umbilical wall and shoulder, without developing into a clearly differentiated bulla. The ribs are narrow, distant, prorsiradiate, feebly flexuous, straight on the inner flank and feebly concave on the outer flank and ventrolateral shoulder. They strengthen progressively across the flanks and link to small inner ventrolateral clavi. A broad rib strengthens and links to larger outer ventrolateral clavi. The venter is not preserved.

DISCUSSION: The present specimen is very close to the paralectotype figured by Anderson (1902, pl. 1, fig. 11). Evolute coiling, rectangular whorl section, coarse distant ribs, together with persistence of inner and outer ventrolateral clavi separate $S$. branneri from the other Subprionocylus recognised in the Haute-Normandie fauna. Subprionocyclus hitchinensis (Text-fig. 5I) is involute, compressed, finely and densely ribbed, and lacks inner ventrolateral tubercles. Subprionocyclus bravaisianus (d'Orbigny, 1841) (p. 308, pl. 91, figs 3,4; see Matsumoto and Noda 1966, p. 360, pl. 40, figs 1-8; Kennedy and Juignet in Gauthier 2006, p. 112, pl. 60, figs 3,4 ) is very compressed, evolute, with crowded flexuous ribs and feeble ventrolateral tuberculation in the holotype. Subprionocyclus normalis Anderson, 1958 (p. 268, pl. 25, fig. 8; see below) is compressed and involute, with blunt flexuous ribbing.

OCCURRENCE: Upper Turonian, neptuni/plana Zone, southern England. Haute-Normandie and Vaucluse in France, Germany, Japan, and Oregon in the United States.

Subprionocyclus normalis (Anderson, 1958)

(Text-fig. 5G, H)

1958. Oregoniceras normale Anderson, p. 268, pl. 25, fig. 8 . 1979. Subprionocyclus normalis (Anderson); Wright, p. 321, pl. 5, fig. 12; pl. 7, fig. 2 (with synonymy).
2014. Subprionocyclus normalis (Anderson, 1958); Amédro and Devalque in Robaszynski et al., p. 158.

TYPE: the holotype is the original of Anderson, 1958, p. 268, pl. 25, fig. 8, 8a, housed in the collections of the California Academy of Sciences, San Francisco, from the Forty Nine Mine, between Meilen and Phoenix, Oregon.

MATERIAL: SP, two fragments labelled "Amm.fleuriausianus? d'Orb Fécamp, C. à Amm.”.

DESCRIPTION: The fragments are preserved as pale brown phosphatic internal moulds. The more complete specimen (Text-fig. 5G, H) is a fragment of body chamber with a maximum preserved whorl height of $42.7 \mathrm{~mm}$. Coiling is very involute, the umbilicus small, shallow, with a low, convex wall and narrowly rounded umbilical shoulder. The unfigured fragment has prominent bullae that project into the umbilicus and give rise to flexuous prorsiradiate ribs, either singly or in pairs; the inner flanks are poorly preserved in the figured fragment. The ribs are broad, flat, strengthening progressively across the flanks, and linking to feeble inner, and much stronger outer ventrolateral clavi, from which a broad rib projects forwards to form an obtuse ventral chevron with a strong siphonal clavus at the apex.

DISCUSSION: The compressed whorl section, involute coiling and broad, flexuous ribs separate these fragments from other species that occur in Haute-Normandie. They compare well with the holotype (Anderson 1958, p. 268, pl. 25, fig. 8), and specimens from the Chalk Rock of southern England (Wright 1979, pl. 5, fig. 12; pl. 7, fig. 2).

OCCURRENCE: Upper Turonian, neptuni/plana Zone, southern England, Haute-Normandie and Vaucluse in France, southern Germany, Japan, and Oregon in the United States.

\section{Suborder Ancyloceratina Wiedmann, 1966 \\ Superfamily Turrilitoidea Gill, 1871 \\ Family Anisoceratidae Hyatt, 1900 Genus Allocrioceras Spath, 1926}

TYPE SPECIES: Crioceras ellipticum Woods, 1896 (non Hamites ellipticus Mantell, 1822, p. 122, pl. 23, fig. 9), by the original designation of Spath 1926, p. $80=$ Hamites angustus J. de CUSgwerbicineDixon, 1850 p. 346, pl. 293 Gingldad Date | 9/26/17 1:08 PM 
Allocrioceras nodiger (F.Roemer, 1870)

(Text-fig. 6A-D)

1841. Hamites ellipticus Mant.; F. A. Roemer, p. 93, pl. 14, fig. 5 .

non 1850. Hamites strangulatus d'Orbigny, p. 215.

1870. Toxoceras nodiger F. Roemer, p. 341, pl. 29, figs 19-21.

1979. Allocrioceras strangulatum Wright, p. 291 (pars), pl. 1, figs 12-13; pl. 2, fig. 1; non pl. 1, fig. 14= Allocrioceras schlueteri (Windmöller, 1882).

1989. Allocrioceras strangulatum Wright, 1979; Kaplan, p. 79 , pl. 4 , fig. 3 ; pl. 7 , fig. 2 ; pl. 8 , figs $1-4$; pl. 9, fig. 1 .

1991. Allocrioceras nodiger (Roemer, 1870); Tarkowski, p. 121, pl. 23, figs 4,7 .

TYPE: Roemer refers to several specimens in his account of Toxoceras nodiger, and figured one of these syntypes (1870, pl. 341, pl. 29, figs 19-21), from the Upper Turonian of Bladen (now Włodzienin) in southern Poland. It has not been traced.

MATERIAL: There are two specimens in the Sorbonne Collections, both from Le Trépot, one labelled "banc à Am. Pros" (Text-fig. 5A,B), the other labelled "couche G, p. 151".

DESCRIPTION: The first specimen (Text-fig. 6A, B) is an internal mould of a slightly curved body chamber fragment $26.1 \mathrm{~mm}$ long, preserved as a pale cream-coloured phosphate. The maximum preserved whorl height of 10.5 $\mathrm{mm}$, the whorl breadth to height ratio 0.75 . The dorsum is broadly rounded, the flanks feebly convex, converging to the more narrowly rounded venter, to give a compressed ovoid intercostal whorl section. The rib index is 4-5, the ribs weak and transverse on the dorsum, strengthening across the dorsolateral margin, and feebly prorsiradiate on the flanks, across which they strengthen progressively. All of the ribs bear small, sharp ventral clavi, linked across the venter by a low, broad, transverse rib. Toward the adapertural end of the fragment, an interspace is wider and deeper than the others, and is a poorly defined constriction, most obvious on the flanks and venter.

The second specimen (Text-fig. 6C, D) is in similar preservation, and is part phragmocone, $19.4 \mathrm{~mm}$ long, slightly curved, with a maximum preserved whorl height of $7.6 \mathrm{~mm}$ and a whorl breadth to height ratio of 0.87 . The dorsum and venter are broadly rounded in intercostal section, the flanks feebly convex and converging towards the venter to give a whorl section comparable to that of the previous specimen. The rib index is 4.5. The ribs are feebly prorsirsdiate and feebly convex on the flanks, across which they strengthen. Of the nine that are well-preserved, six have well-developed ventral clavi, two very weak clavi, and one lacks a clavus. The ribs are broad and transverse on the venter.

DISCUSSION: Allocrioceras strangulatum Wright, 1979 , is a junior synonym of nodiger. The holotype is BMNH C79490, the original of Wright 1979, pl. 1, fig. 13, from the Upper Turonian neptuni/plana Zone fauna of the Chalk Rock of Hitch Wood, near Hitchin, Hertfordshire. Complete individuals of Allocrioceras nodiger are coiled in an open, elliptical criocone, most or all ribs with septate ventral spines, the ribs occasionally linked in pairs at spines; there are occasional constrictions. Allocrioceras billinghusti Klinger, 1976, the second Allocrioceras species recognised in Haute-Normandie, is coiled in a low helix, the ornament markedly asymmetric as a result. Ribs with well-developed septate spines alternate with those with no, or feebly developed spines.

OCCURRENCE: Upper Turonian neptuni/plana Zone. There are also records from southern England, northern France, the Münster Basin in Germany, Poland, and Kazakhstan.

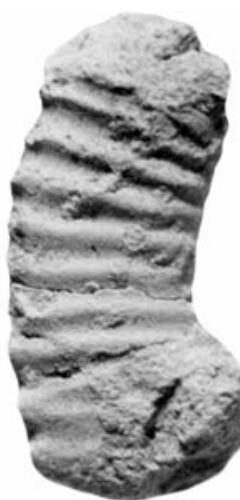

A

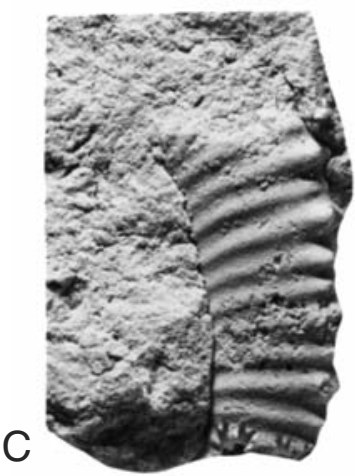

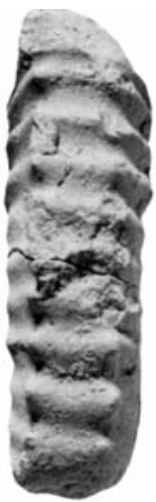

B

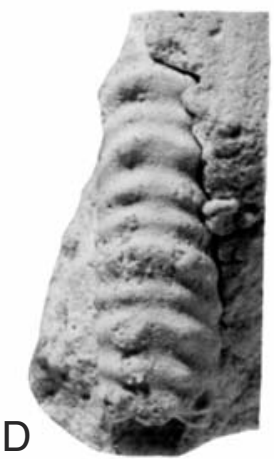

Text-fig. 6. A-D, Allocrioceras nodiger (F. Ronticated from the Upper Turonian neptuni/plana Zone of le Treport. Figures are $\times 2$ 
Allocrioceras billinghursti Klinger, 1976

(Text-fig. 7I, J)

1976. Allocrioceras billinghursti (Wright ms) Klinger, p. 32, pl. 9 , fig. 2; text-fig. $7 \mathrm{~b}$.

1979. Allocrioceras billinghursti Klinger; Wright, p. 292, pl. 2, figs 2,3 .

1989.Allocrioceras billinghursti Klinger, 1976; Kaplan,

p. 78, pl. 4, figs 1, 2, 4, 5; pl. 5, figs 1-3; pl. 6, figs 1, 2 .

1989. Allocrioceras billinghursti Klinger, 1976; Cobban and Kennedy, p. 173, figs 1a-f.

2014. Allocrioceras billinghursti Klinger, 1876; Wilmsen and Nagm, p. 226 text-fig. 13e, f.

TYPES: The holotype, by the original designation of Klinger (1976, p. 32), is the original of Geinitz (1874, pl. 35, fig. 16). The originals of Geinitz (1874, pl. 35, figs $13,14)$ are paratypes; the latter is referred to Allocrioceras nodiger (F. Roemer, 1870). All three specimens are housed in the collections of the Staatlichen Museum für Mineralogie und Geologie, Dresden, and are from the Upper Turonian Strehlen Limestone of Saxony, Germany. They were refigured by Kaplan (1989) and Wilmsen and Nagm (2014). Paratype BMNH C32298 is the original of Billinghurst (1927, pl. 16, fig. 7), from the Upper Turonian neptuni/plana Zone fauna of the Chalk Rock of Hitch Wood near Hitchin, Hertfordshire. A further two paratypes, SAM Z1598 (Klinger 1976, pl. 9, fig. 2) and SAM Z2069, are from the Middle Coniacian of KwaZulu-Natal, South Africa.

MATERIAL: OUM KZ20981, from the Upper Turonian neptuni/plana Zone Senneville 2 Hardground at the top of the Formation de Senneville at Senneville.

DESCRIPTION: The specimen is a $38 \mathrm{~mm}$ long fragment of phosphatised phragmocone with a maximum preserved whorl height of $18 \mathrm{~mm}$. The whorl section is compressed oval, the coiling in a very shallow, open helix. The rib index is six. The ribs are narrower than the interspaces, and markedly asymmetric as a result of the helicoid coiling. They are weak and prorsiradiate on the inner whorl face, strengthening and markedly convex on the upper whorl face, and straight and markedly prorsirsdiate on the outer whorl face. Alternate ribs bear a pair of tubercles, one on the lower part of the face, the other close to the junction of the outer and lower whorl face. The ribs on the lower face weaken, and are very feebly concave.

OCCURRENCE: Upper Turonian neptuni/plana Zone fauna of the Chalk Rock of Hertfordshire, England and the neptuni Zone of northern France and Germany.
Middle Turonian of Natrona County, Wyoming, and Middle Coniacian of KwaZulu-Natal, South Africa

Family Nostoceratidae Hyatt, 1894

Genus and subgenus Hyphantoceras Hyatt, 1900

TYPE SPECIES: Hamites reussianus d' Orbigny, 1850, p. 218, by the original designation of Hyatt (1900, p. 587).

\section{Hyphantoceras (Hyphantoceras) reussianum \\ (d' Orbigny, 1850) \\ (Text-fig. 7C, D)}

1850. Hamites reussianus d' Orbigny, p. 216.

1968. Hyphantoceras reussianum (d'Orbigny); Tröger, p. 45 (pars), pl. 1, figs 2, ?3; text-fig.1, non pl. 1, fig. 1, textfig. 2 = Hyphantoceras flexuosum (Schlüter, 1872)

1979. Hyphantoceras reussianum (d'Orbigny); Wright, p. 297, pl. 2, figs 6, 7; pl. 7, figs 4, 6 .

1988. Hyphantoceras reussianum (d'Orbigny, 1850); Kaplan and Schmid, p. 53, pl. 4, figs 1, 2; pl. 5, figs 1-6; pl.6, figs $1-4$; pl. 7 , figs $1-3$; pl. 8 , figs $1-4$; pl.9, figs $1-3$; pl.10, figs $1-4$; pl. 11, figs $1-5$; pl. 12, figs $1-4$ (with synonymy).

2014. Hyphantoceras reussianum (d'Orbigny, 1850); Amédro and Devalque in Robaszynski et al., p. 162, pl. 39, fig. 12.

2014. Hyphantoceras reussianum (d'Orbigny, 1850); Wilmsen and Nagm, p. 232 text-fig. $15 \mathrm{a}, \mathrm{e}, \mathrm{f}$.

TYPE: d'Orbigny referred to pl. 24, fig. 7 in Reuss 1845, when introducing his species reussi. The original, which has not been traced (Kaplan and Schmid 1988 , p. 53) is the holotype by monotypy. It was from the Plänermergel of Kystra, Slavětin, in the Czech Republic.

MATERIAL: OUM KX25596-99, from the Upper Turonian neptuni/plana Zone Senneville 2 Hardground at the top of the Formation de Senneville at Senneville.

DESCRIPTION: The material consists of four fragments, phosphatised internal moulds of phragmocone and body chamber, with whorl heights of 14-20 mm. OUM KZ25597 (Text-fig. 7C, D) is typical. Coiling is in a low helix. The whorl section is circular. The inner whorl face is near-smooth, with very faint traces of crowded transverse riblets, and some deepened interspaces. Ribbing strengthens across the upper whorl face, and differentiates intontwoneategeries of prorsirs-

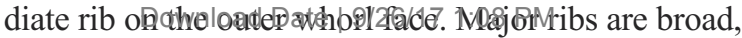




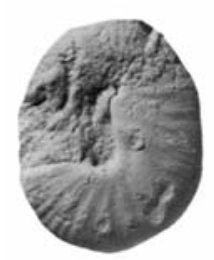

A

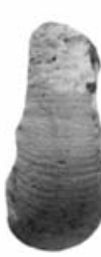

B

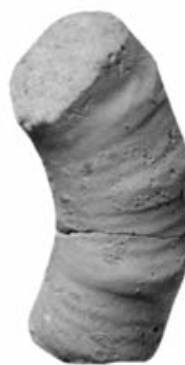

C

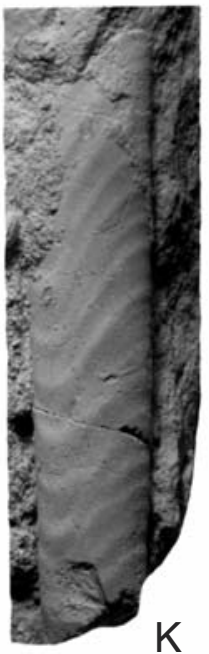

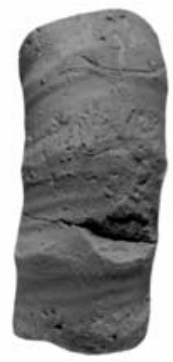

D
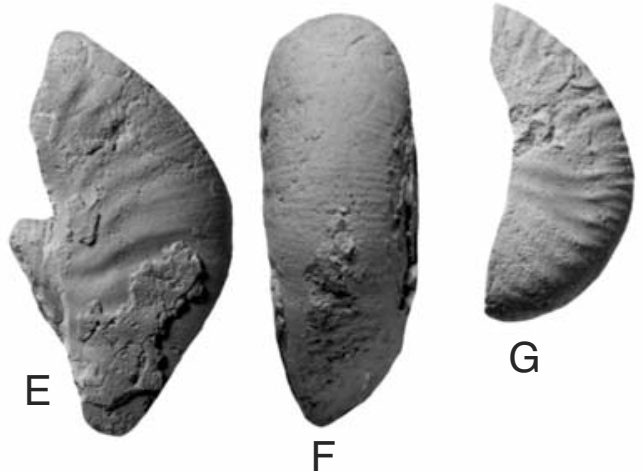

G
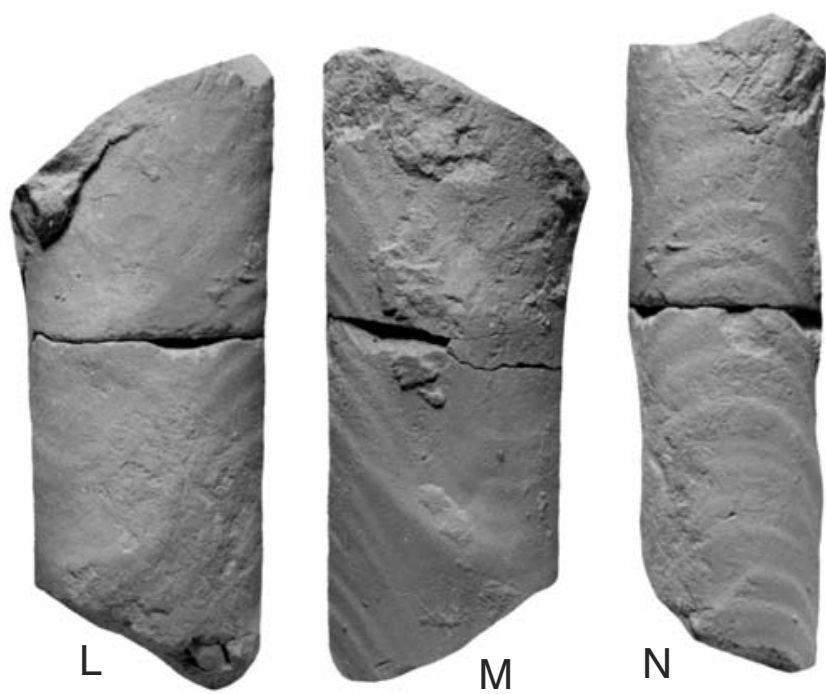

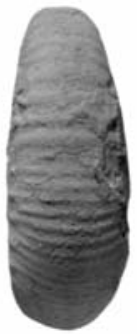

$\mathrm{H}$

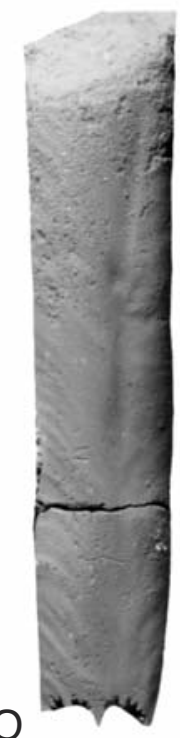

Text-fig. 7. A, B, E-H - Scaphites geinitzii d'Orbigny, 1850, A, B, E, F, SP Collections, from Mers-les-Bains; G, H, Hébert Collection, from Le Petit Andely. C, D - Hyphantoceras reussianum (d'Orbigny, 1850). OUM KZ25597, from the Upper Turonian neptuni/plana Zone Senneville 2 Hardground at the top of the Formation de Senneville at Senneville. I, J - Allocrioceras billinghursti Klinger, 1976, OUM KZ20981, from the same horizon and locality as C, D. K-O - Sciponoceras bohemicum bohemicum (Fritsch, 1872). K, OUM KZ21002; L-N, OUM KZ20999; O, OUM KZ20998, all from the same horizon and locality as C-D. All figures are $\times 1$

and bear traces of the flat-toped bases of two rows of septate spines, separated by up to four weaker, nontuberculate ribs.

DISCUSSION: The ornament of these fragments is very typical of $H$. reussianum, and matches that of more complete specimens figured by Kaplan and Schmid (1988), who discusses differences from other species.

OCCURRENCE: Upper Turonian neptuni/plana Zone fauna of the Chalk Rock and correlatives in southern England, Linconshire and Yorkshire; northern and southeastern France, Germany, the Czech Republic, Poland, northern Spain, Russia, and, possibly, Sakhalin and Tunisia.

Family Baculitidae Gill, 1871

Genus Sciponoceras Hyatt, 1894
TYPE SPECIES: Hamites baculoides Mantell, 1822, p. 123, pl. 23, figs 6,7 , by original designation by Hyatt, 1894, p. 578.

Sciponoceras bohemicum bohemicum (Fritsch, 1872) (Text-fig. $7 \mathrm{~K}-\mathrm{O}$ )

1872. Baculites faujassi Lamarck var. bohemica Fritsch, p. 49, pl. 13, figs 23-25, 29, 30 .

1979. Sciponoceras bohemicum (Fritsch); Wright, p. 285 , pl. 1, figs 3-5; pl. 7, figs 10, 12 (with synonymy).

2001. Sciponoceras bohemicum (Fritsch, 1872); Klinger and Kennedy, p. 258, text-figs 181a-f; 182 a-g, i-m; 183 a-p.

TYPE: The lectotype, by the subsequent designation of Wright (1979, p. 285), is the original of Baculites faujassi

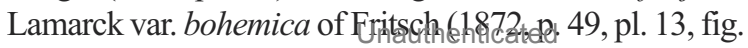

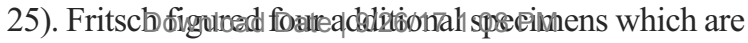


paralectotypes. The type material is from the Upper Turonian of Lenešice, near Louny in the Czech Republic.

MATERIAL: SP, Hébert Collection, labelled "Baculites Fécamp". OUM KZ20998-21003, from the Upper Turonian neptuni/plana Zone Senneville 2 Hardground at the top of the Formation de Senneville at Senneville.

DESCRIPTION: All of the specimens are phosphatic internal moulds of body chamber fragments, with whorl heights of 9.6 to $25 \mathrm{~mm}$. The whorl section is feebly ovoid, with the venter more narrowly rounded than the dorsum. The whorl breadth to height ratio is 0.75 to 0.80. In the smaller specimens, such as OUM KZ21002 (Text-fig. 7K), the primary rib index is three. The ribs are relatively weak on the dorsum, which they cross in a broad convexity, strengthen across the dorsolateral margin, and are markedly concave on the inner flank, from which they project strongly forwards, flex back and are convex on the ventrolateral shoulder, strengthen, and cross the venter in a broad convexity. Additional ribs intercalate, to give a rib index of $4-5$ at the ventrolateral shoulder. OUM KZ20998 (Text-fig. 70 ) is interpreted as a feebly and more densely ribbed variant, the flank ornament interrupted by a longitudinal groove, the result of non-lethal shell damage in life. The ribbing on the outermost flank, ventrolateral shoulder and venter consists of delicate prorsiradiate ribs that sweep back and are convex across ventrolateral shoulders and venter; the ventrolateral rib index is six to seven. Single ribs are periodically strengthened on ventrolateral shoulders and venter, and are succeeded by feeble constrictions. OUM KZ20999 (Text-fig. 7L$\mathrm{N}$ ) is the largest fragment of the species described to date. The ornament is as in the previous specimen, relatively weak, the rib index six at the ventrolateral shoulder, with a rib periodically strengthened, and succeeded by an incipient constriction. Constrictions are better-expressed on the smaller body chamber fragments, presumably those of juveniles.

DISCUSSION: Sciponoceras bohemcium anterius Wright and Kennedy, 1981 (p. 115, pl. 31, figs 4-6, 8, 10, 11, ?7; pl. 32, figs 9, 10, 12-15) of the Upper Cenomanian Neocardioceras juddii Zone differs from the nominate subspecies in having flattened flanks, with frequent constrictions every one and a half to two major diameters, extending across the flanks and present on the dorsum.

OCCURRENCE: Upper Turonian, neptuni/plana Zone, southern England, northwestern France, Germany, northern Spain, The Czech Republic, Austria, Poland, and, possibly, Kazakhstan.

\section{Superfamily Scaphitoidea Gill, 1871 \\ Family Scaphitidae Gill, 1871 \\ Subfamily Scaphitinae Gill, 1871 \\ Genus Scaphites Parkinson, 1811}

TYPE SPECIES: Scaphites equalis J. Sowerby, 1813, p. 53 , pl. 18, figs $1-3$, by the subsequent designation of Meek (1876, p. 413).

\section{Scaphites geinitzii d' Orbigny, 1850 \\ (Text-fig. 7A, B, E-H)}

1850. Scaphites Geinitzii d' Orbigny, p. 214.

1979. Scaphites geinitzii d'Orbigny; Wright, p. 298.

1979. Scaphites geinitzii geinitzii d'Orbigny; Wright, p. 300, pl. 3 , figs $1-4$, pl. 7 , fig. 9 .

1979. Scaphites geinitzii laevior Wright, p. 302, pl. 3, figs 8 , 9 ; pl. 7, fig. 7 .

1979. Scaphites kieslingwaldensis Langenhan and Grundey; Wright, p. 303, pl. 3, figs 10-12.

1987. Scaphites geinitzii d'Orbigny, 1850; Kaplan, Kennedy and Wright, p. 10, pl. 1, figs 1-4, 6-10; pl. 2, figs 1-13; pl. 3, figs 1-5, 9-1; pl. 4, figs 1, 2, 7; pl. 6, fig. 6 (with synonymy).

2014. Scaphites geinitzii d'Orbigny, 1850; Amédro and Devalque in Robaszynski et al., p. 163, pl. 37, fig. 1; pl. 39, fig. 14 .

TYPES: The lectotype, by the subsequent designation of Wright 1979, p. 299, is MNHP R-01235, no. 7179 in the d'Orbigny collection, figured by Wright 1979, pl. 3, fig. 1. MNHP A-25665, d'Orbigny Collection 7179a is a paratype. A further paratype belongs to a different species, and may not be a scaphitid. All are from the Upper Turonian Strehlen Limestone near Dresden, Germany.

MATERIAL: SP, Hébert Collection, from "Le Petite Andely M. Hébert Zone à Holaster planus" (Le Petit Andeley is on the east bank of the Seine in Eure, $32 \mathrm{~km}$ southeast of Rouen). SP, from Mers-les-Bains, Somme. OUM KZ20994-99, four fragments referred to as $S$. cf. geinitzii, from the Upper Turonian neptuni/plana Zone Senneville 2 Hardground at the top of the Formation de Senneville at Senneville.

DESCRIPTION: The best-preserved specimen (Text-fig. 7A, B) is a near-complete addult RAmmelong. The body

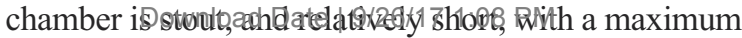


preserved whorl height of $11.1 \mathrm{~mm}$. The umbilical wall is feebly concave, the umbilical shoulder narrowly rounded, the flanks flattened and subparallel, the ventrolateral shoulders broadly rounded, the relatively broad venter feebly convex. Narrow, prorsiradiate flank ribs may bifurcate low on the flank, flexing forwards, and dividing into up to three secondary ribs on the outer flank and ventrolateral shoulder. The ribs bear feeble bullae at the point of branching on the adapertural end of the shaft and on the adapical part of the recurved sector. Additional ribs intercalate on the ventrolateral shoulders and venter, and all ribs are fine, even, and near-transverse on the venter. A larger body chamber fragment (Text-fig. $7 \mathrm{G}, \mathrm{H}$ ) is $32.7 \mathrm{~mm}$ long, with narrow prorsiradiate flank ribs that bifurcate low on the flank and link to small ventrolateral bullae. These give rise to pairs of fine ribs, with a single rib typically intercalating between successive pairs. All ribs are feebly concave on the ventrolateral shoulder, and cross the venter in the feeblest of convexities. The largest fragment (Text-fig. 7D, E) is a body chamber fragment $41.5 \mathrm{~mm}$ long, with very subdued ornament, and does not develop ventrolateral tubercles.

DISCUSSION: The present material falls within the range of variation of Scaphites geinitzii recognised by Kaplan et al. (1987, p. 10) The original of Text-fig. 7A, B, matches their pl. 1, fig. 1 ; Text-fig. 7E, F, their pl. 1, fig. 2; Fig. $7 \mathrm{G}, \mathrm{H}$, their pl. 1, fig. 10. These authors discuss differences between S. geinitzii and related Turonian-Coniacian species.

OCCURRENCE: Upper Turonian. Southern England, north-western and south-eastern France (Vaucluse), Germany, Poland, the Czech Republic, northwestern Spain, Bulgaria, Romania, Ukraine (Crimea, Donbass), Kazakhstan, Turkmenistan, and Greenland.

\section{Acknowledgements}

We are indebted to Professor Pierre Juignet (Université de Caen) for advice, and guidance in the field. We thank Davis Sansom of the Department of Earth Sciences, Oxford, and Marek Ploch (Warsaw) for their assistance in the preparation of the figures. We thank the three anonymous reviewers for their comments on a previous version of the manuscript, and Ulrich Kaplan and Frank Wiese for comments on the present version.

\section{REFERENCES}

Amédro, F., Collete, C., Pietresson De Saint-Aubin, J. and Robasynski, F. 1982. Le Turonien supérieur à Romaniceras
(Romaniceras) deverianum de l'Aube (France). Bulletin d'Information des Géologues du Bassin de Paris, 19, 1937.

Amédro, F., Damotte, R., Manivit, H., Robaszynski, F. and Sornay, J. 1978. Échelles biostratigraphiques dans le Cénomanien du Boulonnais (Pas-de-Calais, F.). Bulletin d'Information des Géologues du Bassin de Paris, 15, 320.

Amédro, F., Damotte, R., Manivit, H., Robaszynski, F. and Sornay, J. 1979. Échelles biostratigraphiques dans le Cénomanien du Boulonnais (macro-micro- nannofossils). Annnales de la Société Géologique du Nord, 98, 287-305.

Amédro, F. and Robaszynski, F. 2000. Les craies à silex du Turonien supérieur au Santonien du Boulonnais (France) au regard de la stratigraphie événementielle. Géologie de France, 4, 39-56.

Amédro, F. and Robaszynski, F. 2001. Les craies Turoniennes du Boulonnais (France) au regard de la stratigraphie événementielle. Comparaison avec le Kent (UK) et la Normandie. Bulletin Trimestrielle de la Société Géologique de Normandie et Amis du Muséum du Havre, 87, 31-49.

Amédro, F. and Robaszynski, F. 2006. Les craies à niveau durcis du Turonien Supérieur-Coniacien Inférieur du Nord de la France (Boulonnais, Artois, environs de Lille): une essai de correlation à l' aide de la stratigraphie événementielle. Annales de la Société Géologique du Nord, 13, 1123-1125.

Anderson, F.M. 1902. Cretaceous Deposits of the Pacific Coast. Proceedings of the California Academy of Sciences (3) Geology, 2, 154 p.

Anderson, F.M. 1958. Upper Cretaceous of the Pacific Coast. Geological Society of America Memoir, 71, xi +378 p.

Basse, E. 1963. Quelques ammonites nouvelles du Crétacé supérieur d'Angola. Bulletin de la Société Géologique de France (7), 4 [for 1962], 871-876.

Billinghurst, S.A. 1927. On some new Ammonoidea from the Chalk Rock. Geological Magazine, 64, 511-518.

Birkelund, T. 1973. A note on Pseudopuzosia sp. from Särdal. Bulletin of the Geological Society of Denmark, 22, 14114.

Bréton, G. and Bavent, M. 1985. Baculites undulatus d'Orbigny, 1850 du Turonien d' Életot près Fécamp (SeineMaritime). Bulletin trimestrielle de la Société Géologique de Normandie et des Amis du Muséum du Havre, $\mathbf{7 2}$, 101-102.

Bromley, R.G. and Gale, A.S. 1982. The lithostratigraphy of the English Chalk Rock. Cretaceous Research, 3, 273306.

Čech, S. 1989. Upper Cretaceous Didymotis Events from Bohemia. In: Wiedmann, J. (Ehdutherataceses of the Western Tethys. Doroctedingsab the athird Inteinational Cretaceous 
Symposium, Tübingen, 1987, pp. 657-676. E. Schweizerbart'sche Verlagsbuchhandlung; Stuttgart.

Chatwin, C.P. and Withers, T.H. 1909. Contribution to the fauna of the Chalk Rock. Geological Magazine, New Series, decade 5, 6, 66-68.

Cobban, W.A. and Kennedy, W.J. 1989. A note on the occurrence of Allocrioceras billinghursti Klinger, 1976 (Cretaceous Ammonoidea) in the Middle Turonian of the Western Interior of the United States. Cretaceous Research, 10, 173-175.

Crick, G.C. 1910. Note on two cephalopods (Pachydiscus farmeryi n.sp., and Heteroceras reussianum [d'Orbigny]) from the Chalk of Lincolnshire. Geological Magazine, New Series, decade 5, 7, 345-348.

Desmoulins, C. 1837. Memoire sur les Echinides. Actes de la Société Linnéenne de Bordeaux, 9, 45-364.

Dibley, G.E. 1912. A note on the Chalk Rock in North Kent. Geological Magazine, New Series, decade 5, 9, p. 372.

Dixon, F. 1850. The Geology and Fossils of the Tertiary and Cretaceous Formations of Sussex. 1st Edn., xxxii +423 p. W.J. Smith; Brighton.

Ernst, G., Schmid, F. and Seibertz, E. 1983. Event-Stratigraphie im Cenoman und Turon von NW-Deutschland. Zitteliana, 10, 531-554.

Fritsch, A. 1872. Cephalopoden der böhmischen Kreidformation. 52p. Fr. Rivnac, Prague.

Gale, A.S. 1996. Turonian correlation and sequence stratigraphy of the Chalk in southern England. Geological Society of London Special Publication, 103, 171-195.

Gauthier, H. (Ed.). 2006. Révision Critique de la Paléontologie Française d'Alcide d'Orbigny, 4, Céphalopodes Crétacés. 1-292 +1-662 + 28p. Backhuys; Leiden.

Geinitz, H.B. 1871-1875. Das Elbthalgebirge in Sachsen. Palaeontographica, 20, 1-319 (1-74, 1871; 95-207, 1872; 207-236, 1873; 237-276, 1874; 277-319, 1875).

Gill, T. 1871. Arrangement of the Families of Mollusks. Smithsonian Miscellaneous Collections, 227, xvi +49 p.

Grossouvre, A. de 1894. Recherches sur la craie supérieure. Deuxième partie, Paléontologie. Les ammonites de la craie supérieure. Mémoires du Service de la Carte Géologique détaillé de la France, 264 p.

Grossouvre, A. de. 1901. Recherches sur la craie supérieur. Première partie, Stratigraphie générale. Mémoires pour servir à l'explication la Carte Géologique détaillée de la France, vii $+559 \mathrm{p}$.

Hébert, E. 1875. Ondulations de la Craie dans le Bassin de Paris. Bulletin de la Société Géologique de France, (3), 3, 512-546.

Housă, V. 1967. Lewesiceras Spath (Pachydiscidae, Ammonoidea) from the Turonian of Bohemia. Sbornik Geologických Vĕd, Paleontologie, 9, 7-49.

Hyatt, A. 1889. Genesis of the Arietidae. Smithsonian Contributions to Knowledge, 673, xi $+239 \mathrm{p}$.
Hyatt, A. 1894. Phylogeny of an Acquired Characteristic. Proceedings of the American Philosophical Society, 32, 349-647.

Hyatt, A. 1900. Cephalopoda, pp. 502-604. In: Zittel, K.A. von 1896-1900, Textbook of Palaeontology, transl. Eastman, C.R. Macmillan; London and New York.

Juignet, P. and Bréton, G. 1994. Stratigraphie, rythmes sedimentaires et eustatisme dans les craies turoniennes de la region de Fécamp (Seine-Maritime), France. Bulletin trimestrielle de la Société Géologique de Normandie et des Amis du Muséum du Havre, 81, 55-81.

Jukes-Browne, A.J. and Hill, W. 1904. Memoirs of the Geological Survey of Great Britain. The Cretaceous Rocks of Britain. III. The Upper Chalk of England. $x+566$ p. Wyman and Sons; London.

Kaplan, U. 1988. Die Ammoniten-Subfamilie Collignoniceratinae Wright \& Wright 1951 aus dem Turon (OberKreide) von Westfalen und Niedersachsen (NW-Deutschland). Geologie und Paläontologie in Westfalen, 12, 5-45.

Kaplan, U. 1989. Die heteromorphe Ammonitengattung Allocrioceras Spath aus dem Turon von Nordwestdeutschland. Geologie und Paläontologie in Westfalen, 15, 71105.

Kaplan, U. 1991. Zur Stratigraphie der tiefen Oberkreide im Teutoburger Wald (NW-Deutschland). Teil 2: Turon und Coniac im Steinbruch des Kalkwerks Foerthe, Halle/ Westfalen. Bericht des Naturwissenschaftlichen Vereins für Bielefeld und Umgegend, 32, 125-159.

Kaplan, U. 2011. Turonium und Unterconiacium (Oberkreide) im Steinbruch DIMAC bei Halle (Westfalen), Teutoburger Wald (östliches Münsterlander Kreidebecken). Geologie und Paläontologie in Münsterland, 81, 75-105.

Kaplan, U. and Kennedy, W.J. 1994. Ammoniten des westfälischen Coniac. Geologie und Paläontologie in Westfalen, 31, 1-155.

Kaplan, U. and Kennedy, W.J. 1996. Upper Turonian and Coniacian ammonite stratigraphy of Westphalia, NW Germany. Acta Geologica Polonica, 46, 305-352.

Kaplan, U., Kennedy, W.J. and Wright, C.W. 1987. Turonian and Coniacian Scaphitidea from England and North-West Germany. Geologisches Jahrbuch, A103, 5-39.

Kaplan, U.and Schmid, F. 1988. Die heteromorphen Ammoniten der Gattung Eubostrychoceras und Hyphantoceras aus den Turon NW Deutschlands. Geologie und Paläontologie in Westfalen, 12, 47-87.

Kennedy, W.J. and Juignet, P. 1974. Carbonate banks and slump beds in the Upper Cretaceous (Upper TuronianSantonian) of Haute-Normandie, France. Sedimentology, 21, 1-42.

Klinger, H.C. 1976. Cretaceous heteromorph ammonites from Zululand. Memoir of the Geological Survey of South Africa, 69, 142 p. Unauthenticated

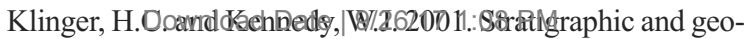


graphic distribution, phylogenetic trends and general comments on the ammonite family Baculitidae Gill, 1871 (with an annotated list of species referred to the family). Annals of the South African Museum, 107, 1-290.

Kossmat, F. 1895-1898. Untersuchungen über die sudindische Kreideformation. Beiträge zur Paläontologie Österreich-Ungarns und des Orients, 9 (1895), 97-203 (1107); 11 (1897), 1-46 (108-153); 11(1898), 89-152 (154-217).

Küchler, T. and Ernst, G. 1989. Integrated biostratigraphy of the Turonian-Coniacian transition interval in northern Spain in comparison to NW Germany. Proceedings of the third International Cretaceous Symposium, Tübingen, 1987, pp. 161-190. E. Schweizerbart'sche Verlagsbuchhandlungen; Stuttgart.

Mantell, G.A. 1822. The fossils of the South Downs; or illustrations of the geology of Sussex, xvi +327 p. Lupton Relfe; London.

Marcinowski, R., Walaszczyk, I. and Olszewska-Nejbert, D. 1996. Stratigraphy and regional development of the midCretaceous (Upper Albian through Coniacian), of the Mangyshlak Mountains, Western Kazakhstan. Acta Geologica Polonica, 46, 1-60.

Matsumoto, T. 1954. Family Puzosiidae from Hokkaido and Saghalien. Memoirs of the Faculty of Science, Kyushu University, Series D, Geology, 5, 69-118.

Matsumoto, T. 1959. The Upper Cretaceous Ammonites of California. Part II. Memoirs of the Faculty of Science, Kyushu University, Series D, Geology, Special Volume 1, $172 \mathrm{p}$.

Matsumoto, T. and Noda, M. 1966. Notes on Ammonites bravaisianus d'Orbigny from the Cretaceous of France. Transactions and Proceedings of the Palaeontological Society of Japan, New Series, 64, 359-365.

Meek, F.B. 1876. A report on the invertebrate Cretaceous and Tertiary fossils of the upper Missouri country in Hayden, F.V. Report of the United States Geological Survey of the Territories, 9, 1xiv $+629 \mathrm{p}$.

Mortimore, R. 1986. Stratigraphy of the Upper Cretaceous White Chalk of Sussex. Proceedings of the Geologists' Association, 97, 97-139.

Mortimore, R. and Pomerol, C. 1987. Correlation of the Upper Cretaceous White Chalk (Turonian to Campanian) of the Ango-Paris Basin. Proceedings of the Geologists 'Association, 98, 97-143.

Orbigny, A. d'. 1840-1842. Paléontologie française: Terrains crétacés. 1. Céphalopodes, 1-120 (1840); 121-430 (1841); 431-662 (1842). Masson, Paris

Orbigny, A. d'. 1850. Prodrome de Paléontologie stratigraphique universelle des animaux mollusques et rayonnés, 2, 427 p. Masson, Paris.

Parkinson, J. 1811. The Organic Remains of a Former World, 3, xv +479 p. J. Robson; London.
Pervinquière, L. 1910. Sur quelques ammonites du Crétacé algérien. Mémoires de la Société Geologique de France, Paléontologie, 17, 86 pp.

Reuss, A.E. 1845. Die Versteinerungen der bömischen Kreideformation, Abt. I, 58 p. E. Schweizerbart'sche Verlagsbuch; Stuttgart.

Robaszynski, F., Amédro, F., Devalque, C. and Matrion, B. 2014. Le Turonien des massifs d'Uchaux et de la Cèze, migration globale d'ammonites et conséquences sur la zonation international, rudistes et corrélations entre les massifs. Mémoires de la classe des Sciences, coll. in $-4^{\circ}$ t, 2, 197 p. Academie royale de Belgique; Bruxelles.

Roemer, F. A. 1840-1841. Die Versteinerungen des norddeutschen Kreidegebirges, 145 p. (1-48, 1840; 49-145, 1841). Hahn'schen Hofbuchhandlung; Hannover.

Roemer, F. 1870. Geologie von Oberschlesien, 587 p. Max Mälzer; Breslau.

Roman, F. and Mazeran, P. 1913. Monographie paléontologique de la faune du Turonien du bassin d'Uchaux et de ses dépendances. Archives du Muséum d'Histoire Naturelle, Lyon, 12, $137 \mathrm{p}$.

Sharpe, D. 1853-57. Description of the fossil remains of Mollusca found in the Chalk of England. I, Cephalopoda. Palaeontographical Society Monographs, 68 p. 1-26, (1853); 27-36 (1855); 37-68 (1857).

Schlüter, C. 1871-1876. Cephalopoden der oberen deutschen Kreide. Palaeontographica, 21, 1-24 (1871); 21, 25 120, (1872); 24, 1-144 (121-264) + x (1876).

Shimizu, S. 1932. On a new type of Senonian ammonite, Pseudobarroisiceras nagaoi Shimizu gen. et sp. nov. from Teshio Province, Hokkaido. Japanese Journal of Geology and Geography, 10, 1-4.

Sowerby, J. 1812-1822. The Mineral Conchology of Great Britain. 1, pls 1-9 (1812), pls 10-44 (1813, pls 45-78 (1814), pls 79-102 (1815); 2, pls 103-14 (1815), pls 11550 (1816), pls 151-86 (1817), pls 187-203 (1818); 3, pls 204-21 (1818), pls 222-53 (1819), pls 254-71 (1820), pls 272-306 (1821); 4, pls 307-18 (1821), pls 319-83 (1822). The Author; London,

Spath, L.F.1922. On the Senonian ammonite fauna of Pondoland. Transactions of the Royal Society of South Africa, 10, 113-147.

Spath, L.F. 1926. On new ammonites from the English Chalk. Geological Magazine, 63, 77-83.

Spath, L.F. 1939. Problems of ammonite nomenclature 6. The genus Pachydiscus Zittel. Geological Magazine, 74, 277-281.

Tarkowski, R. 1991. Stratygrafia, makroskamienialości i paleogeografia utworów górnej kredy niecki opolskiej. Geologia, 51, 1-156.

Tröger, K.-A.1968. Bemerkungen zu Hyphantoceras reussianum (d'Orbigny). Freibragget Eipreshengshefte, C 234,

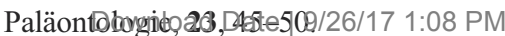


Walaszczyk, I. 1988. Inoceramid stratigraphy of the Turonian and Coniacian strata in the environs of Opole (Southern Poland). Acta Geologica Polonica, 38, 51-61.

Walaszczyk, I. 1992. Turonian through Santonian deposits of the Central Polish Uplands; their facies development, inoceramid palaeontology and stratigraphy. Acta Geologica Polonica, 42, 1-122.

Wiedmann, J. 1966. Stammesgeschichte und System der posttriadischen Ammonoideen; ein Überblick. Neues Jahrbuch für Geologie und Paläontologie Abhandlungen, 125, 49-79; 127, 13-81.

Wiese, F., Wood, C.J. and Kaplan, U. 2004. 20 years of event stratigraphy in NW Germany; advances and open questions. Acta Geologica Polonica, 54, 639-656.

Wilmsen, M. and Nagm, E. 2014. Ammoniten. Geologica Saxonica, 60, 201-240.

Windmöller, T. 1882. Die Entwicklung des Plaeners im nordwestlichen Teile des Teutoburger Waldes bei Lengerich. Jahrbuch der Königlich Preussischen geologischen Landesanstalt und Bergakademie zu Berlin for 1881, 3-54.

Woods, H. 1896. The Mollusca of the Chalk Rock: Part 1. Quarterly Journal of the Geological Society of London, 52, 68-98.
Wray, D. 1999. Identification and long-range correlation of bentonites in Turonian-Coniacian (Upper Cretaceous) chalks of northwest Europe. Geological Magazine, 136, 361-371.

Wright, C. W. 1979. The ammonites of the English Chalk Rock. Bulletin of the British Museum (Natural History) Geology, 31, 281-332.

Wright, C.W. and Kennedy, W.J. 1981. The Ammonoidea of the Plenus Marls and the Middle Chalk. Palaeontographical Society Monographs, 148 pp.

Wright, C.W. and Matsumoto, T. 1954. Some doubtful Cretaceous ammonite genera from Japan and Saghalien. Memoirs of the Faculty of Science, Kyushu University, Series D, Geology, 4, 107-134.

Wright, C.W. and Wright, E.V. 1951. A survey of the fossil Cephalopoda of the Chalk of Great Britain. Palaeontographical Society Monographs, $40 \mathrm{p}$.

Zittel, K.A. von 1884. Handbuch der Palaeontologie. 1, Abt. 2; Lief 3, Cephalopoda, pp. 329-522. R. Oldenbourg; Munich and Leipzig.

Zittel, K.A. von 1895. Grundzüge der Palaeontologie (Palaeozoologie), vii +972 p. R. Oldenbourg; Munich and Leipzig. 